\title{
REVIEW
}

\section{The honeybee disease American foulbrood - An African perspective}

\author{
H. Human ${ }^{1 *}$, C.W.W. Pirk ${ }^{1}$, R.M Crewe ${ }^{1}$ \& V. Dietemann ${ }^{1,2}$ \\ ${ }^{1}$ Department of Zoology and Entomology, University of Pretoria, Pretoria, 0002 South Africa \\ ${ }^{2}$ Swiss Bee Research Center, Agroscope Liebefeld-Posieux, Research Station ALP, 3003 Bern, Switzerland
}

\begin{abstract}
Sustaining apiculture worldwide has been threatened by bee diseases and unexplained colony losses. African honeybee populations seem healthier and no major losses have been reported despite the presence of all the major pests and diseases. The scattered colonies in the large wild population of the continent might ensure slow pathogen spread and thus protect the unmanaged colonies in comparison with the concentration of colonies in managed apiaries. Beekeeping and trade in bee products is responsible for spreading many diseases throughout the world. The recent outbreak of the bacterial disease American foulbrood (AFB) in South Africa is a matter of great concern. Despite a growing number of apiaries testing positive for AFB, no major colony losses have been reported yet. This could be based on higher disease resistance of African honeybees, but such a trait might not persist if pathogens accumulate in the hives. In the first part of this article we review what is known on the history, biology and epidemiology of AFB as well as the control methods available. We then argue that given the particular context of honeybees in Africa, protection policies need to be put in place to ensure that African honeybees remain healthy.
\end{abstract}

Key words: AFB, Paenibacillus larvae, Apis mellifera scutellata, South Africa, brood disease.

\section{INTRODUCTION}

A healthy honeybee population is essential for the agricultural sector as well as for wild flora. The pollination services of honeybees are crucial in food production and the disappearance or decline of honeybee populations could result in not only a depleted and very uniform diet for mankind (Klein et al. 2007) but also in a reduction in agricultural production and hence a threat to world food security (van Engelsdorp \& Meixner 2010). At present, the development of the bee industry worldwide is constrained by bee diseases and consequent colony and economic losses (Neumann \& Carreck 2010; Genersch 2010). African honeybees seem healthier and no large-scale deleterious effects have been reported in spite of the fact that all the major diseases (local or introduced) and honeybee pests and parasites are present with the exception of the Tropilaelaps mites (Dietemann et al. 2009). However, the South African beekeeping industry and honeybee-dependent agriculture has been at risk from the early 1990s as a result of the emergence of invasive social parasitism by workers of Apis mellifera capensis (Dietemann

*To whom correspondence should be addressed.

E-mail: hhuman@zoology.up.ac.za et al. 2006), unique to the country, and from spread of the varroa mite since 1997. The industry may now be in jeopardy following a recent outbreak of American foulbrood (AFB) (Baxter 2009; Department of Agriculture March 2009; http://www.oie.int/wahis/public.php). These events highlight the vulnerability of the bee population in Africa. The situation on the continent and in South Africa in particular might therefore not be as idyllic as believed and the recent AFB outbreak supports the idea that precautions should be adopted to prevent large-scale colony losses as experienced in other parts of the world (Dietemann et al. 2009). The ability of beekeepers to identify pathogens, understand their life histories, and have the knowledge of the most appropriate control measures is essential to keep honeybees healthy and to make beekeeping successful.

AFB is one of the most severe bee diseases (Riessberger-Galle et al. 2001; Brødsgaard et al. 1998). It is classified as a List B disease by the OIE (Office International des Epizooties / World Organization for Animal Health) and is considered a transmissible disease of socio-economic 
importance (De Graaf et al. 2006). It is a notifiable disease in all 178 OIE-member countries. Many of these countries by law require the destruction of affected colonies (Matheson \& Reid 1992; Ratnieks 1992; Fries \& Raina 2003; Waite et al. 2003).

\section{HISTORY OF THE IDENTIFICATION OF AFB AS A HONEYBEE DISEASE}

Aristotle (384-322 BC) described in his Historia animalium a honeybee disease that 'is indicated in a lassitude on the part of the bees and in malodorousness of the hive' (cited in Genersch 2008). AFB cannot be identified with certainty from this description but it suggests that it was observed in ancient times. In 1769, Schirach, a Saxon naturalist, gave the name 'foulbrood' to a disease among honeybees that was characterized by a foul smell of the colony (Schirach 1769; Genersch 2008). In 1882, a distinction was made between a 'mild and curable' (possibly European foulbrood) and a 'malignant and incurable' foulbrood (possibly American foulbrood) by Dzierzon (1882).

At first it was thought that the causative agent of these foulbrood diseases was the bacteria Bacillus alvei but it became evident at the start of the 20th century that there were in fact two foulbrood diseases: European foulbrood caused by Melissococcus plutonius with a frequent secondary invader Bacillus alvei and American foulbrood caused by Bacillus larvae as described by White (1906). Several taxonomical revisions followed with the final status resulting in 2006 in the species Paenibacillus larvae (Genersch et al. 2006). Since then a wide range of strains of $P$. larvae that all cause the typical AFB symptoms have been described. Recently Genersch et al. (2006) identified four genotypes (ERIC I to ERIC IV) of these bacteria with different levels of virulence (Genersch et al. 2005, 2006).

\section{BIOLOGY/PATHOGENESIS/EPIDEMIOLOGY}

Paenibacillus larvae that causes AFB is a rodshaped, Gram-positive bacterium that forms endospores which germinate when conditions are favourable (Chantawannakul \& Dancer 2001). Adult honeybee workers are not affected by AFB spores but are carriers. They infect the larvae while feeding them food contaminated with the infectious spores. The younger the larvae, the more susceptible they are to infection (RiessbergerGalle et al. 2001; Brødsgaard et al. 1998). The spores germinate in the larval midgut, approximately one day after ingestion. The bacterial rods then multiply in the midgut before breaking through the gut wall into the haemolymph, killing the larvae (Yue et al. 2008). The larval remains degrade to a brownish, sticky substance that eventually dries down to a dark, hard scale adhering tightly to the cell wall containing millions of infective spores (reviewed in Genersch 2008).

AFB spores are very stable. They were found to remain in the tract of infected adult bees for more than two months. These spores remained viable, resulting in the infection and death of the larvae consuming them (Wilson 1971). Spores in bee faeces remained viable $600 \mathrm{~h}$ after being egested; indicating that faeces excreted in the immediate vicinity of the hive can function as a reservoir of the pathogen for future infection (Wilson 1972). Spores are also very resistant to adverse conditions such as temperature extremes, the effect of chemicals and desiccation. They can remain viable for 30 to 50 years in hive products, e.g. honey, hive equipment and in scales (dried out larvae) (Haseman1961; Bakhiet \& Stahly 1985; Shimanuki \& Knox 1994).

AFB bacterial spores can be present in a colony without triggering the disease. Moreover, the number of spores causing clinical symptoms is highly dependent on susceptibility of the individual colony. The appearance of clinical symptoms of AFB is influenced by factors such as the age and resistance of larvae, the hygienic behaviour of adult bees that remove infected larvae as well as environmental factors such as temperature, quality and quantity of pollen and nectar (Sutter et al. 1968; Rinderer \& Rothenbuhler 1969; Rinderer \& Rothenbuhler 1974; Brødsgaard et al. 2000). AFB not only kills the infected individuals but can be lethal to the colonies if present in large quantities (Ratnieks 1992; Genersch 2008). Hives with light infections may recover but with 100 or more infected larvae the colony is unlikely to survive (Ratnieks 1992).

\section{TRANSMISSION OF AFB}

Beekeeping (including exchange of hive material such as honey, brood combs and bees between colonies) is a major cause of AFB transmission within and between apiaries (Matheson \& Reid 1992; Goodwin et al. 1994; Pfeiffer \& Crailsheim 1998). Apicultural practices also endanger 
unmanaged colonies in the vicinity of the apiaries (Fries \& Raina 2003). Contaminated honey may serve as a reservoir of AFB spores that are dispersed when bees consume these stores (Hornitzky 1998; Fries \& Camazine 2001; Lindstrom 2008; Lindstrom et al. 2008).

Transmission of this disease can be either horizontal or vertical (Fries \& Camazine 2001). Horizontal transmission within a colony occurs through the remains of dead larvae. Eight to $19 \%$ of larvae reared in cells that previously contained infected larvae will also be infected. In addition, bees that were responsible for cleaning the cells that contained infected larvae can transmit the bacteria when they become nurse bees (Ratnieks 1992; Fries \& Camazine 2001). Horizontal transmission between colonies can occur when bees rob the reserves stored in contaminated nests or when contaminated foragers drift into foreign hives. Vertical transmission is the transmission of AFB spores from parent to offspring. In honeybees this occurs at the colony level during reproductive swarming (Fries \& Camazine 2001; Fries et al. 2006). There is no trans-ovarial transmission from the queen to her offspring, i.e. at the individual level, given that the bacteria are confined to the gut of larvae.

The wax moth, Galleria mellonella, can contribute to the spread of AFB spores (Ritter 1996) as can the small hive beetle, Aethina tumida (Schäfer et al. 2010). However, since the moth and beetle destroy large amounts of comb in the deserted nests of infected colonies that absconded, they may also cause a decrease in general infection pressure.

\section{PREVENTION AND CONTROL}

Efficient AFB control depends on the timely detection of infected and/or diseased colonies and the elimination of infected material since the disease is highly contagious. This can be achieved through regular inspection of apiaries with sufficient knowledge and skills to correctly diagnose the problem in the first place. The only reliable control measure is the killing of bees and burning of contaminated hive material. Waite et al. (2003) have shown that destruction of colonies by burning is very effective in lowering the levels of disease. However, colony and material destruction and the associated costs are unacceptable to many beekeepers.
Beside this efficient but destructive method, there are a variety of methods, of varying efficacy, used for the treatment of infected colonies (discussed in detail by Matheson \& Reid 1992). Although the use of antibiotics has been banned in several countries they are still widely used. Their efficiency is questionable since only clinical symptoms are suppressed whereas the infectious spores are not removed or killed. In addition, residues of antibiotics have been found in honey from treated colonies (Ratnieks 1992; Ghose \& Hawkins 2006) and the development of resistant strains of $P$. larvae to these products has already been reported from South America, U.S.A., Canada, U.K. and Poland (Evans 2003; Miyagi et al. 2000). Antibiotics not only promote the development of resistant bacterial strains but also reduce the life expectancy of honeybees and disrupt the normal microflora and fauna of the beehive (Charbonneau et al. 1992).

Alippi et al. (1996) reported the effectiveness of natural products such as lemon grass, Cymbopogon citratus, and thyme, Thymus vulgaris, against $P$. larvae and cinnamon oil is said to completely inhibit its growth (Chantawannakul \& Dancer 2001). However, Albo et al. (2003) showed that neither the pure essential oils nor the blends were effective in the elimination of clinical AFB symptoms. Further research on the effectiveness of natural products as colony treatment is needed.

Given the lack of satisfying control measures, prevention is of central importance. Gamma irradiation is used in Australia and South Africa to inactivate spores of $P$. larvae in infected hives, pollen and honey (to be used for feeding bees) and limit the spread of the bacteria (Hornitzky \& Wills 1983). Other economically viable and readily available control measures are sterilization of hives and equipment through scorching with a blowtorch and immersion in paraffin wax heated to $150^{\circ} \mathrm{C}$ (Matheson 1992) or a boiling lye solution (Morse \& Shimanuki 1990). New Zealand has been using the immersion in paraffin wax for 50 years even though only $80 \%$ of the spores are destroyed. Such a decrease in bacteria number might be enough to reduce the outbreak of AFB. Fumigation with ethylene oxide $(\mathrm{EtO})$ is another method of sterilization that is said to kill $P$. larvae spores but it leaves toxic residues and has thus been banned in several countries (Charbonneau et al. 1992). Residual infectivity with a high recurrence of AFB was also observed in new bee colonies established on combs treated with this method (Matheson 
1992; Gochnauer et al. 1979; Knox et al. 1976). EtO is a time-consuming, costly process not guaranteed to be efficient (Ratnieks 1992).

According to Brødsgaard \& Hansen (2003) European honeybees colonies are able to survive AFB infection when treated with the shook swarm method'; adult honeybees are transferred without their combs into a clean, disease free hive. Removal of brood effectively minimizes the number of spores in a diseased colony (Lindstrom \& Fries 2005; Fries et al. 2006). This method is similar in effect to absconding (Fries \& Raina 2003). Several versions of the method have been developed, but all variants are labour-intensive, and economically only marginally attractive. However, they allow for the saving of infected colonies without the use of chemicals and the potential risk of bacteria becoming resistant (Matheson \& Reid 1992).

The ideal control method is one that requires neither chemical nor labour investment. This can be achieved if honeybees are resistant to a particular disease. Most honeybees are susceptible to AFB, but some populations are resistant. This resistance is influenced by food, e.g. a queen larva that receives the least amount of pollen is more susceptible to infection compared to drone larvae that receive mostly pollen (Rinderer \& Rothenbuhler 1969). One of the mechanisms limiting the spread of P. larvae is filtering of AFB spores by the ventriculus in the bee honey crop so that they are not transmitted to nestmates through exchange of food. This filtering is more efficient in resistant bee strains (Genersch 2008). Hygienic behaviour of bees is another important resistance mechanism at colony level against $\mathrm{AFB}$ when bees rapidly detect, uncap and remove infected and dead brood (see review in Spivak \& Gilliam 1998a,b; Spivak \& Reuter 2001). This removal of infected larvae is very important and contributes to healthier colonies (Brødsgaard \& Hansen 2003). Hygienic behaviour is a trait at the colony level (Spivak \& Reuter 2001) and breeding of hygienic lines has resulted in bees with increased resistance to AFB infections but thus far no fully AFB-resistant lines have been bred (Hansen \& Brødsgaard 1999).

\section{DISTRIBUTION OF AFB IN SUB-SAHARAN AFRICA}

Even though the geographical origin of AFB is unknown, AFB is, with the exception of sub-Saharan Africa (excluding Eritrea, the Gambia, Guinea-
Bissau, Senegal and until recently South Africa) and tropical countries, reported worldwide (Matheson 1996; Ellis \& Munn 2005; de Graaf et al. 2006). The rarity of AFB outbreaks in Africa can be explained by the biology of wild honeybees. Although there are no data on AFB transmission in wild/unmanaged populations in Africa, dispersed distribution of colonies and accordingly low probabilities for horizontal transmission could ensure colony isolation from pathogens (Fries \& Camazine 2001). Swarms from wild colonies can become infected near managed populations infected with AFB, while those from regions without apiculture rarely contain AFB spores (Fries et al. 2006). The absence of clinical AFB cases in subSaharan Africa could be the result of the traditionally small-scale character of beekeeping (Fries \& Raina 2003). Swarms and thus vertical transmission may be responsible for transmission of $P$. larvae under natural conditions. In addition, the fact that African honeybees, $A$. m. scutellata, more frequently abscond from their hives when disturbed compared to other species (reviewed in Dietemann et al. 2009) may act as 'self-cleansing' after AFB infection. This behavioural trait together with effective hygienic behaviour (Fries \& Raina 2003) may result in low infection pressure and extremely rare development of clinical symptoms (Brødsgaard \& Hansen 2003). It is also possible that African strains of AFB have a low virulence and rarely generate outbreaks.

The effects of beekeeping and international trade in bee products in spreading pathogens, can change the favourable situation experienced in South Africa. It is perplexing that outbreaks of AFB have not been reported in South Africa prior to 2009 since honey and honeybees have been repeatedly imported from the U.S.A. and Europe, where AFB is prevalent (Fries \& Raina 2003). Imported honey, in particular, is likely to be a continuous source of $P$. larvae spores and it is therefore possible for some honeybees to come into contact with enough spores to result in infection.

With the exception of two surveys in the 1990s, there have been no efforts to find AFB in subSaharan Africa through microbiological techniques. Hansen et al. (2003) confirmed the presence of P. larvae in honey produced in South Africa and Guinea Bissau while the survey by Fries \& Raina (2003) found neither spores nor any clinical signs in the colonies or in any honey produced south of the Sahara. Paenibacillus larvae may thus remain 
undetected in large parts of Africa or may be mistaken for the widely distributed EFB (Fries \& Raina 2003). According to a survey by Hansen \& Brødsgaard (2005) honey samples from Burundi and Gambia were free of $P$. larvae. Since honey imported into South Africa is irradiated before marketing it should be impossible to find viable spores. Therefore, although clinical AFB symptoms may be absent from colonies, spores can be present in honey (latent infection), supporting various other studies that showed that there is no correlation between the number of spores in honey and the first clinical signs of AFB in the brood cells (Hansen et al. 2003).

Occurrence of AFB was suspected in South Africa after the Zimbabwean authorities were notified in a report in July 1996 that a colony imported from Johannesburg tested positive for AFB (Beeline 1996). However, following this report, honey samples collected from 57 apiaries were examined and no P. larvae spores were found in the honey. It was therefore concluded that South Africa was AFB free (Davison et al. 1999). This was the case until 2009 when the inspection of honeybee colonies and retail honey by the South African Department of Agriculture (DoA) confirmed the presence of AFB in the Western Cape (Department of Agriculture, March 2009; http://web.oie. int/wahis/public.php). Currently, the extent and distribution of the disease is unknown, and although no monitoring surveys are conducted, inspections are continuing within the A. $m$. scutellata region (Ramsodi 2011). Unfortunately, no precautionary measures are in place to prevent this disease from spreading. Eradication is unlikely and beekeepers and authorities are still considering how to limit the spread of the disease. As a first step, many initiatives to inform the beekeepers about AFB are being put in place.

Losses of honeybee colonies as observed with this outbreak may indicate that the resistance of African honeybees to most diseases might not be the rule if pathogens accumulate in the hives:

\section{REFERENCES}

ALBO, G.N., HENNING, C., RINGUELET, J., REYNALDI, F.J., DE GIUSTI, M.R. \& ALIPPI, A.M. 2003. Evaluation of some essential oils for the control of American foulbrood disease in honey bees. Apidologie 34: 417-427.

ALIPPI, A.M., RINGUELET, J.A., CERIMELE, E.L., RE, M.S. \& HENNING, C.P. 1996. Antimicrobial activity of some essential oils against Paenibacillus larvae, the causal agent of American foulbrood disease. Journal of
Glinsky \& Jarosz (1992) showed that honeybees' susceptibility to fungal and viral infections is altered as soon as they become infected with external parasites. According to Brødsgaard et al. (2000) there seems to be a correlation between varroa infestations and the expression of AFB symptoms by infected colonies. In a further study by De Rycke et al. (2002), Varroa destructor was shown to carry viable $P$. larvae spores and it was concluded that it may act as a vector of AFB.

\section{CONCLUSIONS}

Despite the growing number of reports of AFB outbreaks in the Western Cape region, no major colony losses have been reported. This is similar to the invasion by $V$. destructor that has had no longlasting deleterious effect on South African honeybees (Allsopp 2006). The reason for this higher disease resistance of African bees is not yet fully understood. Legal imports are irradiated but honeybees are increasingly exposed to the pathogen via illegal imports and some measures should be taken to limit further spread of infection. The lack of regulatory measures in South Africa and the resulting problems in addressing the AFB outbreak serves to highlight the importance of each beekeeper becoming aware of these threats and ensuring the maintenance of healthy bees. Honeybee conservation in Africa takes places in a different context than elsewhere in the world because of the large population of wild honeybees. Wild African honeybees represent both an opportunity and a challenge since these populations constitute a reservoir of colonies and genetic material that can buffer some losses, but they also make an epidemic disease a serious ecological and economical issue if threatened. Indeed, it would have tremendous implications for biodiversity and the agricultural sector if the natural population collapses since beekeeping in Africa is not developed to the point where it can alone ensure adequate pollination as it does in other parts of the world.

Herbs, Spices and Medicinal Plants 4: 9-16.

ALLSOPP M. 2006. Analysis of Varroa destructor infestation of southern African populations, M.Sc. thesis University of Pretoria, Pretoria, South Africa.

BAXTER, A. 2009. American foulbrood (AFB) in the Western Cape: advisory notice. South African Bee Journal 81: 8-9.

BAKHIET, N. \& STAHLY, D.P. 1985. Ultrastructure of sporulating Bacillus larvae in broth medium. 
Applied and Environmental Microbiology 50: 690-692.

BEELINE. 1996. Report submitted to Zimbabwean authorities, July 1996. Beeline 33: 5-8.

BRØDSGAARD, C., RITTER, W. \& HANSEN, H. 1998. Response of in vitro reared honey bee larvae to various doses of Paenibacillus larvae larvae spores. Apidologie 29: 569-578.

BRØDSGAARD, C., RITTER, W., HANSEN, H. \& BRØDSGAARD, H.F. 2000. Interactions among Varroa jacobsoni mites, acute paralysis virus, and Paenibacillus larvae larvae and their influence on mortality of larval honeybees in vitro. Apidologie 31: 543-554.

BRØDSGAARD, C. \& HANSEN, H. 2003. Tolerance mechanisms against American foulbrood in honeybee larvae and colonies Apiacta 38: 114-124.

CHANTAWANNAKUL, P. \& DANCER, B.N. 2001. American foulbrood in honey bees. Bee World 82: 168-180.

CHARBONNEAU, R., GOSSELIN, P. \& THIBAULT, C. 1992. Irradiation and American foulbrood. American Bee Journal 132: 249-251.

DAVISON, S., GOVAN, V., LEAT, N. \& ALLSOPP, M. 1999. Bee diseases in South Africa I: EFB, AFB, chalkbrood and bee viruses. South African Bee Journal 77: 84-87.

DE GRAAF, D.C., ALIPPI, A.M., BROWN, M., EVANS, J.D., FELDLAUFER, M., GREGORC, A., HORNITZKY, M., PERNAL, S.F., SCHUCH, D.M.T., TITERA, D., TOMKIES, V. \& RITTER, W. 2006. Diagnosis of American foulbrood in honey bees: a synthesis and proposed analytical methods. Letters in Applied Microbiology 43: 583-590.

DE RYCKE, P.H., JOUBERT, J.J., HOSSEINIAN, S.H. \& JACOBS, FJ. 2002. The possible role of Varroa destructor in the spreading of American foulbrood. Experimental and Applied Acarology 27: 313-318.

DIETEMANN, V., LUBBE, A. \& CREWE, R.M. 2006. Human factors facilitating the spread of a parasitic honeybee in South Africa. Journal of Economic Entomology 99: 7-13

DIETEMANN, V., PIRK, C.W.W. \& CREWE, R. 2009. Is there a need for conservation of honeybees in Africa? Apidologie 40: 285-295.

DZIERZON, J. 1882. Rational Bee-Keeping. Houlston \& Sons, London.

ELLIS, J.D. \& MUNN, P.A. 2005. The worldwide health status of honey bees. Bee World. 86: 88-101.

EVANS, J.D. 2003. Diverse origins of tetracycline resistance in honey bee bacterial pathogen Paenibacillus larvae. Journal of Invertebrate Pathology 83: 46-50.

FRIES, I. \& CAMAZINE, S. 2001. Implications of horizontal and vertical pathogen transmission for honey bee epidemiology. Apidologie 32: 199-214.

FRIES, I. \& RAINA, S. 2003. American foulbrood and African honey bees (Hymenoptera: Apidae). Journal of Economic Entomology 96: 1641-1646.

FRIES, I., LINDSTROM, A. \& KORPELA, S. 2006. Vertical transmission of American foulbrood (Paenibacillus larvae) in honey bees (Apis mellifera). Veterinary Microbiology 114: 269-274.

GENERSCH, E., ASHIRALIEVA, A. \& FRIES, I. 2005. Strain- and genotype-specific differences in virulence of Paenibacillus larvae subsp. larvae, the causative agent of American foulbrood disease in honey bees. Applied Environmental Microbiology 71: 7551-7555.
GENERSCH, E., FORSGREN, E., PENTIKÄINEN, J., ASHIRALIEVA, A., RAUCH, S., KILWINSKI, J. \& FRIES, I. 2006. Reclassification of Paenibacillus larvae subsp. Pulvifaciens and Paenibacillus larvae subsp. larvae as Paenibacillus larvae without subspecies differentiation. International Journal of Systematic Evolutionary Microbiology 56: 501-511.

GENERSCH, E. 2008. Paenibacillus larvae and American foulbrood - long since known and still surprising. Journal of Consumer Protection and Food Safety 3: 429-434.

GENERSCH, E. 2010. American foulbrood in honeybees and its causative agent, Paenibacillus larvae. Journal of Insect Pathology 103: S10-S19.

GHOSE, A. \& HAWKINS, C. 2004. A bio-economic evaluation of the American foulbrood (AFB) control program in Western Australia. Australian Agricultural and Resource Economics Society; 2004 Conference (48th), February 11-13, Melbourne, Australia.

GLINSKY, Z. \& JAROSZ, J. 1992. Varroa jacobsoni as a carrier of bacterial infections to a recipient bee host. Apidologie 23: 25-31.

GOCHNAUER, T.A., FURGALA, B. \& SHIMANUKI, H. 1979. Diseases and enemies of the honey bee. In: Graham, J.M. (Ed.) The Hive and the Honey Bee. 617-619. Dadant \& Sons, Hamilton, IL.

GOODWIN, R.M., PERRY, J.H. \& TEN-HOUTEN, A. 1994. The effect of drifting honey bees on the spread of American foulbrood infections. Journal of Apicultural Research 33: 209-212.

HANSEN, H. \& BRØDSGAARD, C.J. 1999. American foulbrood: a review of its biology, diagnosis and control. Bee World 80: 5-23.

HANSEN, H., BRØDSGAARD, C. J., KRYGER, P. \& NICOLAISEN, M. 2003. A scientific note on the presence of Paenibacillus larvae larvae spores in sub-Saharan African honey. Apidologie 34: 471-472.

HANSEN, H. \& BRØDSGAARD, C.J. 2005. The spread and control of American foulbrood. Bees for Development Journal 76: 12.

HASEMAN, L. 1961. How long can spores of American foulbrood live? American Bee Journal 101: 298-299.

HORNITZKY, M.A.Z. 1998. The spread of Paenibacillus larvae subsp. larvae infections in an apiary. Journal of Apicultural Research 37: 261-265.

HORNITZKY, M.A.Z. \& WILLS, P.A. 1983. Gamma radiation inactivation of Bacillus larvae to control American foulbrood. Journal of Apicultural Research 22: 196-199. Online at: http://web.oie.int/wahis/public.php (accessed August 2011).

KLEIN, A-M., VAISSIÈRE, B.E., CANE, J.H., STEFFAN-DEWENTER, I., CUNNINGHAM S.A., KREMEN, C. \& TSCHARNTKE, T. 2007. Importance of pollinators in changing landscapes for world crops. Proceedings of the Royal Society B 274: 303-313.

KNOX, D.A., SHIMANUKI, H. \& CARON, D.M. 1976. Ethylene oxide plus oxytetracycline for the control of American foulbrood in honeybees. Journal of Economic Entomology 69: 606-608.

LINDSTROM, A. \& FRIES, I. 2005. Sampling of adult bees for detection of American foulbrood (Paenibacillus larvae subsp. larvae) spores in honey bee (Apis mellifera) colonies. Journal of Apicultural Research 44: 82-86. 
LINDSTROM, A. 2008. Distribution of Paenibacillus larvae spores among adult honey bees (Apis mellifera) and the relationship with clinical symptoms of American foulbrood. Microbial Ecology 56: 253-259.

LINDSTROM, A., KORPELA, S. \& FRIES, I. 2008. The distribution of Paenibacillus larvae spores in adult bees and honey and larval mortality, following the addition of American foulbrood diseased brood or sporecontaminated honey in honey bee (Apis mellifera) colonies. Journal of Invertebrate Pathology 99: 82-86.

MATHESON, A. 1996. World bee health update. Bee World 77: 45-51.

MATHESON, A. \& REID, M. 1992. Strategies for the prevention and control of American foulbrood: Part 1 of a three-part series. American Bee Journal. 132: 399-401.

MIYAGI, T., PENG, C.Y.S., CHUANG, R.Y., MUSSEN, E.C., SPIVAK, M.S. \& DOI, R.H. 2000. Verification of oxytetracycline-resistant American foulbrood pathogen Paenibacillus larvae in the United States. Journal of Invertebrate Pathology 75: 95-96.

MORSE, R.A. \& SHIMANUKI, H. 1990. Summary of control methods. In: Morse, R.A. \& Nowogrodzki, R. (eds) Honey Bee Pests, Predators and Diseases. 2nd Edn. 341-361. Cornell University Press, Ithaca, NY

NEUMANN, P. \& CARRECK, N.L. 2010. Honey bee colony losses. Journal of Apicultural Research 49: 1-6.

PFEIFFER, K.I.J. \& CRAILSHEIM, K. 1998 Drifting of honeybees. Insectes Sociaux 45: 151-167.

RAMASODI, M. 2011. Response to a letter addressed by the South African Bee Industry to the Acting Chief Director: Plant Health and Inspection Services. South African Bee Journal 83: 9-13.

RATNIEKS, F.L.W. 1992. American foulbrood: the spread and control of an important disease of the honeybee. Bee World 73: 177-191.

RIESSBERGER-GALLE, U., VON DER OHE, W. \& CRAILSHEIM, K. 2001. Adult honeybee's resistance against Paenibacillus larvae larvae, the causative agent of the American foulbrood. Journal of Invertebrate Pathology 77: 231-236.

RINDERER, T.E. \& ROTHENBUHLER, W.C. 1969. Resistance to American foulbrood in honey bees. X. Comparative mortality of queen, worker and drone larvae. Journal of Invertebrate Pathology 13: 81-86.

RINDERER, T.E. \& ROTHENBUHLER, W.C. 1974. The influence of pollen on the susceptibility of honey-bee larvae to Bacillus larvae. Journal of Invertebrate Pathology 23: 347-350.

RITTER, W. 1996 Diagnostik und Bekämpfung von Bienenkrankheiten. Gustav Fischer Verlag, Jena.

RAMASODI, M. 2011. Response to a letter addressed by the South African Bee Industry to the Acting Chief
Director: Plant Health and Inspection Services. South African Bee Journal 83: 9-13.

SCHÄFER, M.O., RITTER, W., PETTIS, J. \& NEUMANN, P., 2010. Small hive beetles, Aethina tumida, are vectors of Paenibacillus larvae. Apidologie 41: 14-20.

SCHIRACH, G.A. 1769 Der sächsische Bienenmeister, oder kurze Anweisung für den Landman zur Bienenzucht, nebst beygefügtem oekonomischen Bienencalender. Auf Veranlassung und auf Kosten der gnädigst bestätigten wirtschaftlichen Gesellschaft in Leipzig, Leipzig.

SHIMANUKI, H. \& KNOX, D. 1994. Susceptibility of Bacillus larvae to terramycin. American Bee Journal 134: 125-126.

SPIVAK, M. \& GILLIAM, M. 1998. Hygienic behavior of honey bees and its application for control of brood diseases and varroa: Part II Studies on hygienic behavior since the Rothenbuhler era. Bee World 79: 169-186.

SPIVAK, M. \& REUTER, G.S. 2001. Resistance to American foulbrood disease by honey bee colonies Apis mellifera bred for hygienic behavior. Apidologie 32: 555-565.

SUTTER, G.R., ROTHENBUHLER, W.C. \& RAUN, E.S. 1968. Resistance to American foulbrood in honey bees VII. Growth of resistant and susceptible larvae. Journal of Invertebrate Pathology 12: 25-28.

VANENGELSDORP D. \& MEIXNER, M.D. 2010. A historical review of managed honey bee populations in Europe and the United States and the factors that may affect them. Journal of Invertebrate Pathology 103: S80-S95.

WAITE, R., BROWN, M., THOMPSON, H. \& BEW, M. 2003. Control of American foulbrood by eradication of infected colonies. Apiacta 38: 134-136.

WHITE, G.F. 1906. The bacteria of the apiary with special reference to bee disease. USDA, Bureau of Entomology, Technical Series 14: 1-50.

WILSON, W.T. 1971. Resistance to American foulbrood in honey bees XI. Fate of bacillus larvae spores ingested by adults. Journal of invertebrate Pathology 17: 247-255.

WILSON, W.T. 1972. Resistance to American foulbrood in honey bees XII. Persistence of viable Bacillus larvae spores in the feces of adults permitted flight. Journal of Invertebrate Pathology 20: 165-169.

YUE, D., NORDHOFF, M., WIELER, L.H. \& GENERSCH, E. 2008. Fluorescence in situ hybridization (FISH) analysis of the interactions between honeybee larvae and Paenibacillus larvae, the causative agent of American foulbrood of honeybees (Apis mellifera). Environmental Microbiology 10: 1612-1620. 